\title{
Pengaruh Pemberian Air Nira Aren (Arengga Pinnata Merr) Secara Oral Terhadap Konsumsi Hijauan dan Pertambahan Bobot Badan Kambing Peranakan Etawa (PE)
}

\author{
Adi Hardiyansyah ${ }^{1}$, Aisyah Nurmi ${ }^{2}$, Luky Wahyu Sipahutar ${ }^{2}$ \\ 1,2,3 Program Studi Peternakan Fakultas Peternakan Universitas Muhammadiyah Tapanuli Selatan \\ e-mail :adlo.m93@gmail.com
}

\begin{abstract}
Abstrak
Penelitian ini bertujuan untuk mengetahui pengaruh pemberian air nira aren (Arengga Pinnata Merr) secara oral terhadap konsumsi hijauan serta pertambahan bobot badan kambing Peranakan Etawa (PE). Penelitian dilaksanakan dikandang "Helo Farming Group (HFG)" Desa Siapporik Lombang Kabupaten Tapanuli Selatan selama dua bulan. Kambing PE yang digunakan adalam kambing betina berumur 1,5-2 tahun dangan bobot yang seragam. Penelitian dirancang dengan menggunakan rancangan bujur sangkar latin (RBSL) 5 x 5: yaitu 5 perlakuan serta 5 pengulangan terhadap sampel. Subjek penelitian yaitu lima ekor kambing PE. Hasil penelitian yang telah dilakukan menunjukkan adanya pengaruh pemberian air nira aren secara oral terhadap tingkat konsumsi pakan hijauan. Sedangkan untuk pertambahan bobot badan hasil analisis menunjukkan tidak adanya pengaruh yang nyata pemberian air nira aren secara oral pada kambing PE.
\end{abstract}

Kata Kunci : Kambing PE, air nira aren, oral

\section{PENDAHULUAN}

Ternak kambing Peranakan Etawa (PE) di Indonesia dikembangkang sebagai salah satu sumberdaya penghasil bahan makanan berupa daging dan susu yang memiliki nilai ekonomi yang tinggi, dan penting artinya bagi masyarakat. Kambing Peranakan Etawa (PE) umumnya masih lebih dominan sebagai sumber daging dibandingkan dengan sumber air susu. Susu kambing belum dikenal secara luas seperti susu sapi padahal memiliki komposisi kimia yang cukup baik sebagai produk konsumsi. Kandungan protein susu kambing sebesar 4,3\% dan lemak 2,8\% sedangkan kandungan protein susu sapi yaitu protein 3,8\% dan lemak 5,0\% (Sunarlim dkk, 1992). Disamping itu menurut 
Sunarlim dkk, (1992) susu kambing lebih mudah dicerna karena ukuran molekul lemak susu kambing lebih kecil dan secara alamiah sudah berada dalam keadaan homogen. Dilihat dari segi produktivitas biologis, kambing Peranakan Etawa mencapai 28\% lebih tinggi dibandingkan sapi (Devendra, 1994). Jumlah anak per kelahiran (litter size) bervariasi satu sampai dengan tiga ekor dengan tingkat produksi susu yang melebihi dari kebutuhan untuk anaknya, sehingga dapat dimanfaatkan sebagai produk komersial dan tidak mengganggu proses reproduksinya.

Biaya investasi usaha ternak kambing relatif rendah dan pemeliharaannya pun jauh lebih mudah dibanding sapi. Namun, manajemen pemeliharaan dan pemberian pakan yang baik diperlukan untuk meningkatkan produktivitas ternak kambing Peranakan Etawa. Lingkungan sekitar dan konsumsi pakan ternak merupakan salah satu faktor yang mempengaruhi produktivitas ternak. Ketersediaan pakan sepanjang tahun merupakan persyaratan mutlak bagi kelangsungan usaha kambing PE. Biaya untuk menyediakan pakan ini menempati porsi terbesar dalam biaya produksi mencapai $60-$ $80 \%$.

Oleh karena itu perlu dicari inovasi inovasi hasil dari buah pemikiran (penelitian) yang dapat diaplikasikan juga berguna bagi masyarakat untuk mencari pemecah sebuah masalah penggunaan konsumsi pakan pada ternak ruminansia atau dengan kata lain dapat menekan konsumsi pakan sehingga semakin terjaga ketersediaan hijauan bagi ternak ruminansia dimasa mendatang. Bisa saja dengan pemberian nira aren secara berkala dapat meningkatkan pertambahan bobot badan dan juga dapat meningkatkan imun tubuh ternak terhadap suatu penyakit.

Nira adalah cairan yang disadap dari bunga jantan pohon aren (Arengga Pinnata Merr), cairan ini mengandung gula antara 10 $15 \%$. Dalam keadaan segar nira berasa manis, berbau khas nira dan tidak berwarna. Nira aren mengandung beberapa zat gizi antara lain karbohidrat, protein, lemak dan mineral. Rasa manis pada nira disebabkan oleh kandungan karbohidratnya mencapai 11,28\% (Rumokoi, 1990). Aren memiliki kandungan kimia yang berguna dan dapat dimanfaatkan oleh tubuh, kandungan yang dapat ditemukan adalah sukrosa.

Menurut Pontoh (2007) nira aren mengandung sukrosa dan gula reduksi yaitu glukosa, fruktosa dan polisakarida. Adapun komposisi kimia pada 100 gram nira menurut Susanto dan Saneto (1994) adalah air sebanyak 87,2 gram; protein sebanyak 0,2 gram; lemak sebanyak 0,02 gram; karbohidrat sebanyak 12,34 gram dan abu sebanyak 0,24 gram. Menurut Safari (1995) gula aren yang mengandung glukosa mempunyai banyak khasiat, salah satunya dapat membersihkan ginjal sehingga 
terhindar dari penyakit ginjal. Pemanfaatan air nira aren (Arengga Pinnata Merr) sebagai bahan tambahan minum terhadap kambing Peranakan Etawa diharapkan berpotensi untuk meningkatkan nafsu makan juga sekaligus meningkatkan bobot hihup kambing Peranakan Etawa.

\section{METODOLOGI PENELITIAN}

\section{Tempat dan Waktu Penelitian}

Penelitian dilaksanakan dikandang "Helo Farming Group (HFG)" yang berlokasi di Desa Siapporik Lombang Kabupaten Tapanuli Selatan. Lama penelitian yang dilakukan terhadap Kambing Peranakan Etawa berlangsung selama dua (2) bulan.

\section{Rancangan Penelitian}

Penelitian dilaksanakan secara eksperimental dan dirancang dengan menggunakan rancangan bujur sangkar latin (RBSL) 5 x 5: yaitu 5 perlakuan serta 5 pengulangan terhadap sampel. Subjek penelitian yaitu lima (5) ekor kambing peranakan etawa (PE) betina berumur 1,5-2 tahun yang telah dipilih berdasarkan keseragaman bobot badan, serta keadaan fisik (sehat). Kambing ditempatkan dalam kandang yang telah disekat dengan ukuran $\mathrm{p}$ x $1=0,75$ x 1,20 $\mathrm{m}$. Sedangkan perlakuan diberikan nira aren (Arengga Pinnata Merr) melalui mulut (diminumkan/oral) terhadap kambing peranakan etawa (PE) $2 \mathrm{x}$ sehari yaitu pada pagi hari setelah kambing mengkonsumsi pakan $( \pm 15$ menit setelah mengkonsumsi pakan) dan juga sore hari $( \pm 15$ menit setelah mengkonsumsi pakan).

\section{Teknik Pengumpulan Data}

Teknik pengumpulan data dilakukan dengan mengambil (mencatat) data satu kali dalam seminggu dari hasil perlakuan. Adapun kelima perlakuan pemberian air nira aren (Arengga Pinnata Merr) melalui mulut (oral) tersebut sebagai berikut:

P1: Tanpa pemberian air nira aren (Arengga Pinnata Merr)

P2: Pemberian air nira aren (Arengga Pinnata Merr) sebanyak 2 × $20 \mathrm{ml} / \mathrm{hari}$

P3: Pemberian air nira aren (Arengga Pinnata Merr) sebanyak 2 × $25 \mathrm{ml} / \mathrm{hari}$

P4: Pemberian air nira aren (Arengga Pinnata Merr) sebanyak 2 x $30 \mathrm{ml} / \mathrm{hari}$

P5: Pemberian air nira aren (Arengga Pinnata Merr) sebanyak 2 x $35 \mathrm{ml} / \mathrm{hari}$

Tabel 1. Rancangan Perlakuan RBSL 5 x 5

\begin{tabular}{|l|l|l|l|l|}
\hline P1 & P2 & P3 & P4 & P5 \\
\hline P2 & P5 & P4 & P1 & P3 \\
\hline P3 & P4 & P1 & P5 & P2 \\
\hline
\end{tabular}




\begin{tabular}{|l|l|l|l|l|}
\hline P4 & P3 & P5 & P2 & P1 \\
\hline P5 & P1 & P2 & P3 & P4 \\
\hline
\end{tabular}

\section{Analisis Data}

Data yang diperoleh dianalisis dengan menggunakan sidik ragam (Analysis of Variance) berdasarkan Steel dan Torrie (1995). Jika terdapat hasil berbeda nyata maka dilanjutkan dengan uji Duncan's Multiple Range Test (DMRT) dan uji Beda Nyata Jujur $(\mathrm{BNJ})$.

\section{Parameter Yang Diukur}

Parameter yang diukur dalam penelitian ini adalah

\section{Konsumsi Pakan}

Jumlah pemberian dan jumlah sisa pakan ditimbang setiap hari untuk menghitung jumlah konsumsi pakan dengan cara mengurangi jumlah pakan yang diberikan dengan sisa pakan setiap kambing dan setiap hari pada setiap perlakuan.

Konsumsi pakan $=$ Jumlah pakan yang diberikan - Jumlah pakan yang dikonsumsi.

2. Pertambahan berat badan (PBB)

Pertambahan bobot badan harian kambing dihitung dengan menggunakan rumus:
PBBH $=$ Bobot badan akhir - Bobot Badan awal Lama Pemeliharaan

\section{Prosedur Penelitian}

Penelitian dibagi menjadi dua tahap, yaitu tahap pertama adalah tahap pendahuluan yang bertujuan untuk mengetahui daya konsumsi pakan kambing PE sehingga dapat menentukan kebutuhan konsumsi kambing PE per ekor per hari dan tahap kedua adalah pengambilan data serta pengukuran pertambahan bobot badan, konsumsi pakan dan konversi pakan. Tahap pendahuluan dilakukan selama dua (2) minggu, dan pengambilan data selama lima (5) minggu dengan jarak waktu istirahat perlakuan selama lima (5) hari tiap minggu perlakuan.

\section{HASIL DAN PEMBAHASAN}

\section{Konsumsi Pakan}

Dari data hasil penelitian yang telah dilakukan didapatkan hasil rataan konsumsi pakan hijauan Kambing PE betina dewasa selama penelitian sebagai berikut:

Tabel 2. Konsumsi Pakan Hijauan Kambing PE Betina Dewasa Selama Penelitian (g/ekor/hari)

\begin{tabular}{|c|c|c|c|c|c|c|c|}
\hline \multicolumn{7}{|c|}{ Rataan Konsumsi (g/ekor/hari) } \\
\hline & K1 & K2 & K3 & K4 & K5 & Total & Rataan \\
\hline P1 & 3124,29 & 3606,43 & 3410,00 & 3240,00 & 3514,29 & 16895,00 & 3379,00 \\
\hline P2 & 3242,86 & 3157,86 & 3630,00 & 3424,29 & 3470,00 & 16925,00 & 3385,00 \\
\hline
\end{tabular}




\begin{tabular}{|c|c|c|c|c|c|c|c|} 
P3 & 3352,14 & 3555,71 & 2947,86 & 3511,43 & 3270,71 & 16637,86 & 3327,57 \\
\hline P4 & 3412,86 & 3485,71 & 3259,29 & 3010,71 & 3595,00 & 16763,57 & 3352,71 \\
\hline P5 & 3519,29 & 3372,14 & 3542,86 & 3352,86 & 3155,71 & 16942,86 & 3388,57 \\
\hline Total & 16651,43 & 17177,86 & 16790,00 & 16539,29 & 17005,71 & $\mathbf{8 4 1 6 4 , 2 9}$ & \\
\hline Rataan & 3330,29 & 3435,57 & 3358,00 & 3307,86 & 3401,14 & & $\mathbf{3 3 6 6 , 5 7}$ \\
\hline
\end{tabular}

Hasil pencatatan konsumsi pakan hijauan dari Tabel 2 diatas diketahui bahwa total konsumsi pakan hijauan pada kelompok K4 adalah yang terendah yaitu sebesar 16539,29 (g) dengan rataan sebesar 3307,86 (g/ekor/hari). Sedangkan rataan konsumsi pakan hijauan tertinggi pada K2 sebesar 17177,86 (g) dengan rataan sebesar 3435,57 (g/ekor/hari).

Untuk rataan konsumsi pakan hijauan pada perlakuan, perlakuan P3 adalah yang terendah yaitu sebesar 16637,86 (g), dengan rataan konsumsi sebesar 3327,57 (g/ekor/hari). Rataan konsumsi pakan hijauan pada perlakuan, kelompok P5 adalah yang tertinggi yaitu sebesar 16942,86 (g) dengan rataan konsumsi 3388,57 (g/ekor/hari).

Tabel 3. Analisis Sidik Ragam Konsumsi Pakan Hijauan Kambing PE Betina Dewasa Selama Penelitian (g/hari)

\begin{tabular}{|c|c|c|c|c|c|c|}
\hline \multirow{2}{*}{$\begin{array}{c}\text { SUMBER } \\
\text { KERAGAMAN }\end{array}$} & \multirow{2}{*}{$\begin{array}{c}\text { DERAJAT } \\
\text { BEBAS } \\
\text { (DB) }\end{array}$} & \multirow{2}{*}{$\begin{array}{c}\text { JUMLAH } \\
\text { KUADRAT } \\
(\text { JK) }\end{array}$} & \multirow{2}{*}{$\begin{array}{c}\text { KUADRAT } \\
\text { TENGAH } \\
(\text { KT })\end{array}$} & \multirow{2}{*}{ F-HITUNG } & \multicolumn{2}{|c|}{$\mathbf{F}_{\text {TABEL }}$} \\
\hline & & & & & 0,05 & 0,01 \\
\hline BARIS (Periode) & 4 & 752255,06 & 188063,77 & $87,50 * *$ & 3,26 & 5,41 \\
\hline KOLOM (Kambing) & 4 & 54061,77 & 13515,44 & $6,29 * *$ & 3,26 & 5,41 \\
\hline PERLAKUAN & 4 & 13455,51 & 3363,88 & $1,57^{\mathrm{tn}}$ & 3,26 & 5,41 \\
\hline GALAT & 12 & 25791,33 & 2149,28 & & & \\
\hline TOTAL & 24 & 845563,68 & & & & \\
\hline
\end{tabular}

Keterangan: tn $=$ tidak nyata

$* *$ = sangat nyata

Koefisien Keragaman $(\mathrm{KK})=1,23 \%$
Perbedaan rataan konsumsi pakan hijauan terhadap seluruh perlakuan $(\mathrm{P} 1, \mathrm{P} 2, \mathrm{P} 3, \mathrm{P} 4$ dan P5) pada seluruh sampel kambing tidak menunjukkan perbedaan yang begitu besar dengan rataan konsumsi terendah sebesar 16637,86 (g) dan rataan konsumsi tertinggi sebesar 16942,86 (g). Hal ini dikarenakan seluruh sampel penelitian memperoleh perlakuan yang sama dengan tingkat pemberian air nira aren yang berbeda-beda sehingga pemberian perlakuan tidak menunjukkan perbedaan yang besar terhadap rataan komsumsi pakan selama penelitian.

Adapun analisis sidik ragam konsumsi pakan hijauan sebagai berikut: 
Dari hasil analisis sidik ragam pada Tabel 3 menunjukkan bahwa pemberian air nira aren (Arengga Pinnata Merr) pada perlakuan memberikan pengaruh sangat nyata terhadap rataan konsumsi pakan selama penelitian. Pada uji Beda Nyata Jujur (BNJ) pada baris (periode) dan kolom (kambing) didapatkan hasil uji sebagai berikut:

Tabel 4. Uji Beda Nyata Jujur (BNJ) Periode Konsumsi Pakan Kambing PE Betina Dewasa

\begin{tabular}{|c|c|c|}
\hline Baris (Periode) & Rataan & Notasi \\
\hline P1 & 3379,00 & $\mathbf{a}$ \\
\hline P2 & 3385,00 & $\mathbf{a}$ \\
\hline P3 & 3327,57 & $\mathbf{a}$ \\
\hline P4 & 3352,71 & $\mathbf{a}$ \\
\hline P5 & 3388,57 & $\mathbf{a}$ \\
\hline
\end{tabular}

Tabel 5. Uji Beda Nyata Jujur (BNJ) Kolom Konsumsi Pakan Kambing PE Betina Dewasa

\begin{tabular}{|c|c|c|}
\hline $\begin{array}{c}\text { Kolom } \\
\text { (Kambing) }\end{array}$ & Rataan & Notasi \\
\hline K1 & 3330,29 & a \\
\hline K2 & 3435,57 & b \\
\hline K3 & 3358,00 & $\mathbf{a}$ \\
\hline K4 & 3307,86 & $\mathbf{a}$ \\
\hline K5 & 3401,14 & b \\
\hline
\end{tabular}

Dari hasil uji lanjut BNJ dari setiap perlakuan (P1, P2, P3, P4 dan P5) tidak menunjukkan hasil yang berbeda nyata. Sedangkan pada uji BNJ tingkat konsumsi pakan hijauan pada kolom (kambing) K1, K3 dan K4 (a) berbeda nyata terhadap tingkat konsumsi pakan hijauan pada kolom (kambing) K2 dan K5 (b).

Menurut Lubis (1992), hijauan adalah bahan pakan dalam bentuk daun-daunan yang kadang-kadang masih bercampur dengan batang, ranting serta bunga yang pada umumnya berasal dari tanaman sebangsa rumput dan kacang-kacangan. Hijauan dapat pula diartikan sebagai pakan yang mengandung serat kasar yang relatif tinggi. Menurut Hardianto dan Djajanegara (1993), penggunaan pakan lengkap juga dapat meningkatkan konsumsi, menghindari terjadinya penolakan dalam porsi tertentu terhadap bahan pakan yang tidak disukai. Variasi rumput liar untuk konsumsi ternak pada penelitian ini sangat bermacam-macam jenis.

\section{Pertambahan Bobot Badan}

Hasil penimbangan ternak setiap minggu menunjukkan bahwa pemberian air nira aren secara oral dengan memberikan pakan hijauan berupa rumput liar memperlihatkan adanya peningkatan bobot hidup kambing. Hal ini dapat dilihat pada akhir kegiatan penelitian yang menunjukkan bahwa semua perlakukan (P2, P3, P4, dan P5) mengalami kenaikkan bobot hidup akhir. P1 (tanpa perlakuan) juga mengalami kenaikan bobot hidup akhir. 
Pertambahan bobot badan (PBB) selama penelitian diperoleh data seperti dibawah:

Tabel 6. Pertambahan Bobot Badan (PBB) Kambing PE Betina Dewasa Selama Penelitian (g/ekor/hari)

\begin{tabular}{|c|c|c|c|c|c|c|c|}
\hline \multicolumn{7}{|c|}{ PBB (g/ekor/hari) } \\
\hline Perlakuan & K1 & K2 & K3 & K4 & K5 & Total & Rataan \\
\hline P1 & 114,29 & 71,43 & 157,14 & 142,86 & 85,71 & 571,43 & 114,29 \\
\hline P2 & 157,14 & 271,43 & 100,00 & 114,29 & 85,71 & 728,57 & 145,71 \\
\hline P3 & 85,71 & 85,71 & 414,29 & 85,71 & 271,43 & 942,86 & 188,57 \\
\hline P4 & 128,57 & 114,29 & 228,57 & 271,43 & 57,14 & 800,00 & 160,00 \\
\hline P5 & 128,57 & 157,14 & 114,29 & 100,00 & 157,14 & 657,14 & 131,43 \\
\hline Total & 614,29 & 700,00 & 1014,29 & 714,29 & 657,14 & & \\
\hline Rataan & 122,86 & 140,00 & 202,86 & 142,86 & 131,43 & & \\
\hline
\end{tabular}

Berdasarkan Tabel 6 diatas, tingkat pertambahan bobot badan kambing tertinggi diperoleh pada perlakuan P3 yaitu sebesar 942,86 (g) dengan rataan 188,57 (g/ekor/hari). Pertambahan bobot badan terendah terdapat pada perlakuan P1 yaitu sebesar 571,43 (g) dengan rataan 114,29 (g/ekor/hari).

Akan tetapi pertambahan bobot badan kambing dari data yang diperoleh lebih besar dibandingkan dengan pernyataan dari Mulyono dan Sarwono (2005), dimana pertambahan bobot badan (PBB) kambing yang digemukkan secara intensif bisa mencapai 100 - 150 gram per hari dengan rata-rata 120 gram per hari atau 700 - 1.050 gram dengan rata-rata 840 gram per minggu.

Sehingga diperoleh hasil analisis sidik ragam pertambahan bobot badan kambing PE betina dewasa seperti dibawah:

Tabel 7 Analisis Sidik Ragam Pertambahan Bobot Badan Kambing PE Betina Dewasa Selama Penelitian

\begin{tabular}{|l|c|c|c|c|c|c|}
\hline $\begin{array}{c}\text { SUMBER } \\
\text { KERAGAMAN }\end{array}$ & $\begin{array}{c}\text { DERAJAT } \\
\text { BEBAS } \\
\text { (DB) }\end{array}$ & $\begin{array}{c}\text { JUMLAH } \\
\text { KUADRAT } \\
\text { (JK) }\end{array}$ & $\begin{array}{c}\text { KUADRAT } \\
\text { TENGAH } \\
\text { (KT) }\end{array}$ & \multicolumn{2}{|c|}{ F-HITUNG } & \multicolumn{2}{|c|}{ F $_{\text {Tabel }}$} \\
\cline { 5 - 8 } & 4 & 91542,86 & 22885,72 & $6,99^{* *}$ & 3,26 & 5,41 \\
\hline BARIS (Periode) & 4 & 20032,65 & 5008,16 & $1,53^{\text {tn }}$ & 3,26 & 5,41 \\
\hline KOLOM (Kambing) & 4 & 16032,65 & 4008,16 & $1,22^{\text {tn }}$ & 3,26 & 5,41 \\
\hline PERLAKUAN & 12 & 39281,63 & 3273,47 & & & \\
\hline TOTAL & 24 & 166889,79 & & & & \\
\hline
\end{tabular}

Keterangan: tn $=$ tidak nyata

$* *$ = sangat nyata

Koefisien Keragaman $(\mathrm{KK})=34,58 \%$ 
Berdasarkan Tabel 7 diatas dapat oleh beberapa faktor yaitu total protein yang dinyatakan bahwa pertambahan bobot badan (PBB) kambing pada sumber keragaman baris (Periode) berpengaruh sangat nyata. Sedangkan sumber keragaman kolom (kambing), pertambahan bobot badan (PBB) kambing PE betina dewasa tidak nyata, artinya pemberian air nira aren (Arengga Pinnata Merr) tidak berpengaruh nyata terhadap pertambahan bobot badan (PBB) kambing PE betina dewasa.

Pemberian air nira aren (Arengga Pinnata Merr) terhadap perlakuan yang telah ditentukan tidak memberikan pengaruh nyata terhadap pertambahan bobot badan (PBB) kambing PE betina dewasa dengan cara oral pada tingkat pemberian P1 (tanpa perlakuan), P2 (2 x $20 \mathrm{ml})$,

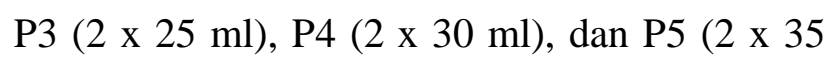
$\mathrm{ml})$.

Hal ini dapat diartikan bahwa dengan pemberian atau tanpa pemberian air nira aren (Arengga Pinnata Merr) pada perlakuan tidak memberikan pengaruh yang nyata terhadap pertambahan bobot badan (PBB) kambing PE betina dewasa dikarenakan kandungan air nira aren tidak cukup baik untuk memberikan pertambahan bobot badan pada kambing jika tidak dibarengi dengan kebutuhan pakan yang sesuai baik berupa protein, nutrisi dan zat gizi lainnya. Seperti yang dikemukakan oleh National Research Council (1985) yang menyatakan bahwa pertambahan bobot tubuh dipengaruhi diperoleh setiap harinya, jenis kelamin, umur, keadaan genetis, lingkungan, kondisi setiap individu dan manajemen pemeliharan dan perkandangan.

\section{KESIMPULAN DAN SARAN}

Berdasarkan hasil analisis data penelitian disimpulkan bahwa pemberian air nira aren (Arengga Pinnata Merr) secara oral terhadap berpengaruh sangat nyata terhadap konsumsi pakan kambing peranakan etawa (PE) betina dewasa namun tidak memberikan dampak terhadap pertambahan bobot badan.

Perlu dilakukan penelitian lebih lanjut tentang pengaruh lain pemberian air nira aren (Arengga Pinnata Merr) secara oral terhadap respon fisiologis dan peningkatan kesehatan ternak kambing Peranakan Etawa (PE) untuk menunjang potensi yang bisa digali dari penggunaan nira aren pada ternak kambing.

\section{Daftar Pustaka}

Devendra C. dan M. Burns. 1994. Produksi Kambing di Daerah Tropis. Bandung: Penerbit ITB.

Haryanto, B. dan Andi Djajanegara. 1993. Pemenuhan Kebutuhan Zat-Zat Pakan Ruminansia Kecil, Dala Produksi Kambing Dan Domba di Indonesia, editor: Monica W., dkk, Solo: sebelas Maret University Press. 
Lubis, D.A. Ilmu Makanan Ternak. 1999. Jakarta: PT Pembangunan.

Mulyono, S. dan B. Sarwono. 2008. Penggemukan Kambing Potong. Jakarta: Penebar Swadaya.

National Research Council, Nutrients Requirements of Goats. 1981. Angora, Dairy and Meat Goats in Temperate and Tropical Countries. Washington D. C,: National Academy Press.

Pontoh J. 2007. Analisa Komponen Kimia Dalam Gula Dan Nira Aren. Tomohon: Laporan pada Yayasan Masarang.

Rumokoi M. 1990. Manfaat Tanaman Aren (Arenga pinnata Merr). Buletin Balitka No. 10 Thn 1990 hal: 21-28. Manado: Balai Penelitian Kelapa.

Safari A. 1995. Teknik Membuat Gula Aren. Surabaya: Karya Anda.

Steel, R. G. D dan J. H. Torrie. 1995. Prinsip dan Prosedur Statistik Suatu Pendekatan Biometrik. Edisi 2, Cetakan 2, Alih Bahasa Bambang Sumantri. PT. Gramedia PustakaUtama, Jakarta.

Sunarlim, R., Triyantini, B. Setiadi dan Setiyanto H. 1992. Upaya mempopulerkan dan meningkatkan penerimaan susu kambing dan domba. Prosiding Sarasehan Usaha Ternak Domba dan Kambing Menyongsong Era PJPTII. ISPI dan PDHF, Bogor.

Susanto T, Saneto B. 1994. Teknologi Pengolahan Hasil Pertanian. Bina Ilmu. Surabaya. 